\title{
PONDOK DARING PADA ERA COVID-19 DI DUSUN BANJAR TENGAH KECAMATAN DAU KABUPATEN MALANG
}

\author{
Ita Suhermin Ingsih*, Dita Wahyu Anggraini, Asrini Safi, Nirza Asyani Kabalmay, \\ Hanif Ubaidillah, Marwan Hanan Attamimi, Mohammad Ilyas, Mahmad Alfian Ni'am, \\ Syahrul Iqbal Kobarubun, Umar Al Faruq \\ Fakultas Teknik, Universitas Islam Malang \\ *Korespondensi email: Ita.suhermin@unisma.ac.id
}

\begin{abstract}
ABSTRAK
Pembelajaran daring merupakan metode belajar yang menggunakan model interaktif berbasis internet dan Learning Manajemen System (LMS). Bentuk pembelajaran seperti ini dapat dilakukan kapanpun dan dimanapun tanpa terikat waktu dan tanpa harus bertatap muka. Tujuan dari program ini adalah untuk membantu siswa yang kesulitan dalam menyelesaikan tugas serta membeli kuota internet selama pendemi di Dusun Banjar Tengah Kecamatan Dau Kabupaten Malang. Menyediakan Wi-Fi disalah satu tempat di Dusun dan memberikan pendampingan terhadap siswa dengan menerapkan sosial distancing dan protokol kesehatan. Masyarakat sekitar sangat mendukung kegiatan pondok daring, hal ini ditandakan dengan rasa antusias yang tinggi dari masyarakat setempat dan siswa siswi di Dusun Banjar Tengah.
\end{abstract}

Kata Kunci: daring; pendidikan; dusun banjar tengah.

\section{PENDAHULUAN}

Dalam Undang-Undang Sistem Pendidikan Nasional No 20 Tahun 2003 disebutkan bahwa pendidikan nasional berfungsi untuk mengembangkan serta membentuk watak peradaban bangsa yang bermartabat untuk mewujudkan cita-cita bangsa, yaitu mencerdaskan kehidupan berbangsa serta berupaya untuk mengembangkan potensi serta kemampuan peserta didik dan menjadikan mereka menjadi manusia yang beriman, berakhlak mulia, berilmu cakap, kreatif, mandiri dan menjadi warga Negara yang demokratis serta tanggung jawab. Seluruh lembaga satuan pendidikan di Indonesia tanpa terkecuali memiliki peran penting untuk merealisasikan fungsi pendidikan nasional tersebut. Semua jenjang pendidikan termasuk sekolah Dasar memiliki peranan penting untuk mewujudkan tujuan pendidikan nasional tersebut (Dalimunthe, 2015).

Kegiatan belajar mengajar di setiap tingkat pendidikan sudah berbeda dengan yang sebelumnya, hal itu dikarenakan dampak dari wabah covid 19 yang menyerang negara indonesia dari awal tahun 2020, sehingga hal itu mengharuskan setiap instansi pendidikan untuk melakukan sistem pembelajaran daring yang bertujuan untuk mencegah penularan virus tersebut.

Pembelajaran daring yaitu penyelenggaraan kelas pembelajaran dalam jaringan untuk menjangkau kelompok target yang massif dan luas, sehingga pembelajaran daring dapat diselenggarakan dimana saja serta diikuti secara gratis maupun berbayar (Bilfaqih \& Qomarudin, 2015). Selain itu, pembelajaran daring memanfaatkan jaringan internet dalam proses pembelajaran dan memberikan metode pembelajaran yang efektif seperti berlatih 
dengan adanya umpan balik (Kurniasih, Rahmati, Umamah, \& Widowati, 2019), menggabungkan kegiatan kolaboratif dengan belajar mandiri, personalisasi pembelajaran berdasarkan kebutuhan anak yang menggunakan simulasi dan permainan (Ghirardini, 2011; Aprilia, Suparman, Eliana, Khairunnissa, \& Sugiarti, 2020). Pembelajaran daring atau penerapan e-learning dalam pendidikan anak usia dini telah menjadi solusi praktis untuk masalah yang dihadapi (Nichols \& McLachlan, 2006; Kurniasih et al., 2019).

Pembelajaran daring memiliki manfaat seperti membangun komunikasi serta diskusi antara guru dengan anak, anak saling interaksi dan berdiskusi dengan satu dan lainnya, memudahkan anak berinteraksi dengan guru dan orang tua, sarana yang tepat untuk melihat perkembangan anak melalui laporan orang tua dengan tujuan orang tua dapat melihat langsung perkembangannya, guru dapat dengan mudah memberikan materi kepada anak berupa gambar, video, dan audio yang dapat diunduh oleh orang tua langsung, dan mempermudah guru membuat materi dimana saja dan kapan saja (Sobron, Bayu, Rani, \& S, 2019; Haryanti, Hidayati, Rodliyah, Nisful Laili, \& Saraswati, 2020).

Namun penduduk di dusun banjar tengah dimana mahasiswa unisma menyelenggarakan pembelajaran daring adalah mayoritas petani atau tukang kebun sehingga selain mereka mempunyai keterbatasan untuk membeli kuota internet untuk dipergunakan pembelajaran daring, mereka juga kesulitan untuk mengurus anaknya dikarenakan harus berangkat kerja di pagi hari. Oleh karenanya pembelajaran daring di dusun tersebut dilakukan di balai dusun dengan sistem yang efektif dan tetap mematuhi protokol covid 19.

\section{METODE}

Program pondok daring upaya memaksimalkan pendidikan pada Era-COVID-19 ini dilaksanakan di Dusun Banjar Tengah, Desa Sumbersekar, Kecamatan Dau Kabupaten Malang dimulai pada tanggal 13 Agustus 2020 sampai dengan tanggal 31 Agustus 2020. Kegiatan ini dilakukan bersama Dosen Pendamping Lapangan dan Mahasiswa kelompok 59 yang dimulai dengan melakukan kegiatan diskusi bersama kepala desa dan kepala dusun terkait rencana pendirian pondok daring di Dusun Banjar Tengah.

Kegiatan KKN-PPM tematik ini di khususkan dalam memaksimalkan pendidikan di Era-COVID-19 yaitu tepatnya di Dusun Banjar Tengah yang dilakukan secara bersama-sama oleh mahasiswa dengan persetujuan Kepala Dusun Banjar Tengah. Kegiatan pondok daring ini meliputi penyediaan Wi-Fi gratis serta mendampingi siswa yang kesulitan dalam mengerjakan tugas.

Adapun tahapan yang dilakukan dalam pelaksanaan kegiatan ini yaitu sebagai berikut:

\section{Survey Lokasi}

Survey lokasi ini bertujuan untuk menyesuaikan antara kegiaan dengan tema tematik yang telah dipilih serta dapat dijadikan objek gambaran apakah ada masalah pendidikan lain selama pendemi yang dapat ditambahkan dalam pelaksanaan kegiatan yang telah direncanakan.

\section{Diskusi Bersama Kepala Dusun Banjar Tengah}

Kegiatan diskusi dilakukan oleh perwakilan dari Mahasiswa KKN. Kegiatan ini dilakukan guna dapat menyatukan antara pemikiran ide rancangan yang dipaparkan oleh Mahasiswa agar rencana yang ingin dikerjakan sesuai dengan kedua belah pihak dan dapat diselesaikan sesuai dengan apa yang telah ditargetkan.

\section{Diskusi Bersama Pihak Sekolah}

Tujuan dari sosialisasi ini untuk mempermudah memberikan informasi kepada pihak wali murid bahwa ada fasilitas Wi-Fi gratis dan pendampingan kepada siswa yaitu 
Pondok Daring di Balai Dusun Banjar Tengah. Mahasiswa unisma menginfokan bahwa pondok daring ini menerapkan sosial distancing dan sesuai dengan protokol kesehatan.

\section{Diskusi dengan Pihak Wali Murid}

Pelaksanaan pondok daring ini melibatkan pelajar yang mayortitas masih tingkat Sekolah Dasar, oleh karena itu perlu adanya sosialisasi kepada pihak wali murid terkait persetujuan dll. Selain memberikan informasi bahwa ada fasilitas Wi-Fi gratis Mahasiswa unisma juga berdiskusi bagaimana berjalannya podok daring kedepannya. Wali murid banyak meberikan masukan terhadap kegiatan ini.

\section{Pemberian Arahan (Desa, Sekolah, Perangkat Masyarakat, Wali Murid, Siswa)}

Pemberian arahan ini sangat penting dilakukan mengingat kegiatan ini dilakukan di tengah-tengah pendemi. Mahasiswa unisma pemeberi arahan kepada wali murid dan siswa bahwa syarat untuk menggunakan fasilitas Wi-Fi di Balai Dusun harus sesuai protokol kesehatan dan menerapkan sosial distancing.

\section{Pelaksanaan Kegiatan}

Mahasiswa unisma menyediakan formulir persetujuan wali murid guna menghindari konflik di tengah pendemi. Setiap siswa yang berkunjung ke pondok Daring wajib menggunakan masker dan selalu menjaga jarak. Mahasiswa unisma menyediakan handsanitaizer untuk para siswa yang berkunjung.

\section{Analisis Kegiatan}

Analisis kegiatan dilakukan guna mengetahui kekurangan pada kegiatan Pondok Daring. Setelah menganalisis kegiatan Mahasiswa unisma akan mengevaluasi kegiatan dan mencari solusi untuk setiap masalah.

\section{Evaluasi Hasil Kegiatan}

Tujuan dari evaluasi untuk mengetahui apa saja yang menjadi kendala selama kegiatan sehingga Mahasiswa unisma dapat menemukan solusi bersama untuk mengatasi kendala yang ada.

\section{HASIL DAN PEMBAHASAN}

Dengan munculnya pendemik Covid-19 kegiatan belajar mengajar yang semula dilaksanakan disekolah kini menjadi belajar di rumah melalui daring. Pembelajaran daring dilakukan dengan menyesuaikan kemampuan masing-masing sekolah. Beberapa sekolah menerapkan sistem daring (online) dengan menggunakan teknologi digital seperti google classroom, zoom dan ada juga yang memakai aplikasi pesan lintas platform seperti WhatsApp Dll.

Sumbersekar Dau merupakan salah satu desa yang masuk dalam wilayah zona merah. Rata-rata masyarakat di desa adalah petani atau tukang kebun sehingga mereka terkendala dalam pembelian kuota internet untuk pembelajaran daring, selain itu wali murid terkendala untuk mengawasai dan mendapingi anaknya dikarenakan harus berangkat kerja setiap harinya.

Dengan beberapa kendala tersebut, pemasangan Wi-Fi disalah satu tempat yaitu balai dusun banjar tengah sekaligus memberikan pendampingan kepada siswa akan meringankan wali murid untuk dalam pembelian kuota internet dan juga membantu wali murid dalam pengawasan dan pendampingan terhadap anaknya.

Pondok daring sangat mematuhi protokol kesehatan, setiap siswa yang datang wajib menggunakan masker. Mahasiswa unisma juga menyediakan handsanitizer, salah satu handsanitizer kepada setiap siswa yang datang dan duduk dengan jarak satu meter.

Selama kegiatan pondok daring berlangsung, Mahasiswa Unisma rutin memberikan pengawasan dan bimbingan terhadap perserta didik yang tidak paham mengenai pelajaran 
ataupun tugas yang diberikan oleh gurunnya, seperti mata pelajaran matematika, bahasa inggris, bahasa arab Dll. Sehingga murid sangat terbantu dengan adanya kegiatan ini.

Kegiatan pondok daring tersebut dilaksakan kurang lebih selama tiga minggu, oleh karena itu setelah kegiatan tersebut selesai Mahasiswa unisma membuatkan grup WhatsApp yang menampung peserta didik dari pondok daring sehingga mahasiswa unisma dapat membantu peserta didik yang kurang memahami mata pelajarannya dengan melalui grup tersebut. Hal tersebut dimaksudkan untuk tindak lanjut dari kegiatan pondok daring,

Kegiatan yang dilakukan selama Pondok Daring di Dusun Banjar Tengah Sumbersekar Kecamatan Dau Kabupaten Malang diantaranya:

\section{Pendaftaran dan Pemasangan Wi-Fi}

Pemasangan Wi-Fi di Balai Dusun Banjar Tengah di proses selama 2 hari. Pendaftaran Wi-Fi dilaksanakan pada tanggal 3 Agustus 2020 pada pukul 13.00 WIB. Dengan biaya sebesar Rp.349.000,- dari uang yang kelompok Mahasiswa unisma kumpulkan. Tanggal 4 Agustus 2020 dilakukan pemasangan modem oleh teknisi. Adanya Wi-Fi yang Mahasiswa unisma sediakan meringankan biaya orang tua siswa yang biasanya mengeluarkan biaya untuk membeli kuota sebesar Rp.60.000,- per bulan menjadi Rp.30.000,- per bulan.

2. Sosialisasi ke Pihak Sekolah SDN Sumbersekar 2 Dau

Kesulitan yang dialami pihak sekolah saat pendemi dalam mengajar yaitu tidak bisa bertatap muka langsung dengan murid sehingga proses belajar mengajar tidak efektif. Pihak Sekolah melakukan video conference akan tetapi terkendala di pihak siswa, tidak semua siswa dapat mengoperasikan aplikasi video converence karena ada orang tua yang masih bekerja, ada juga orang tua yang gagap teknologi. Tujuan dari sosialisasi ini untuk mempermudah memberikan informasi bahwa ada fasilitas Wi-Fi gratis dan pendampingan kepada siswa yaitu Pondok Daring di Balai Dusun Banjar Tengah. Kegiatan ini dilaksanakan pada tanggal 5 Agustus 2020 pada pukul 10.00 WIB oleh seluruh Anggota Kelompok 59.

\section{Sosialisasi dengan penduduk dusun Banjar Tengah}

Penduduk dusun Banjar Tengah cukup antusias terhadap kegiatan pondok daring, kegiatan ini selain membantu pihak sekolah di masa pandemi ini juga meringankan tugas wali murid untuk menjaga sekaligus mengajari anaknya untuk memahami pelajaran ataupun tugas dari sekolah. Oleh karenanya pondok daring mendapatkan dukungan dan respon positif dari kebanyakan penduduk dusun banjar tengah.

\section{Pembukaan Pondok Daring}

Pembukaan Pondok Daring dilakukan pada tanggal 13 Agustus 2020 pada pukul 08.0010.00 WIB. Kegiatan ini dihadiri oleh Kepala Dusun Banjar Tengah, Ketua RW 04 dan Ketua RT 04 Dusun Banjar Tengah, serta Dosen Pembimbing Lapangan (DPL).

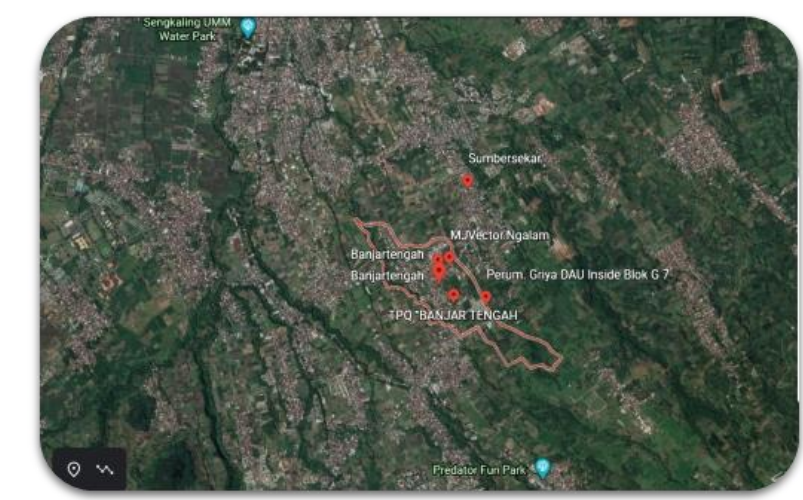

Gambar 1. Peta Lokasi Dusun Banjar Tengah (dok. KKN-PPM) 


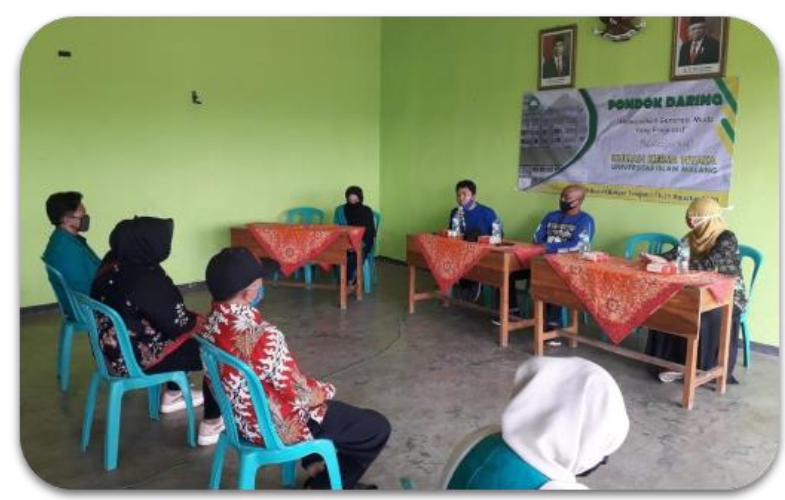

Gambar 2. Pembukaan Pondok Daring (dok. KKN-PPM kel.59)

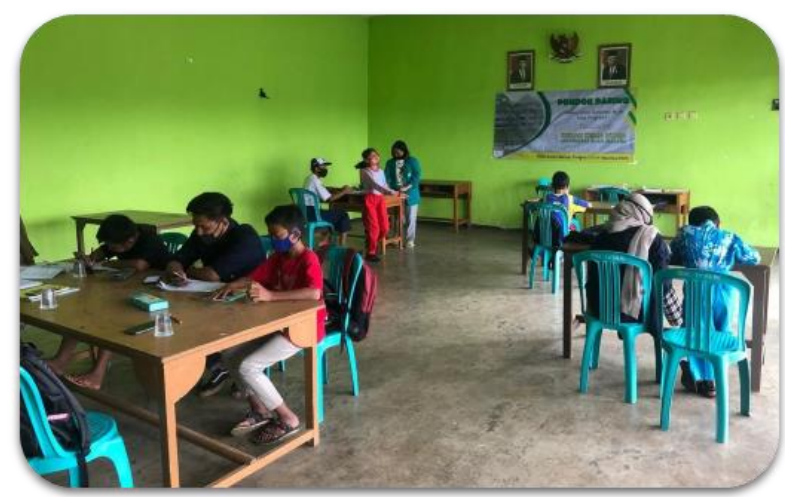

Gambar 3. Pelaksanaan Pondok Daring (dok. KKN-PPM kel.59)

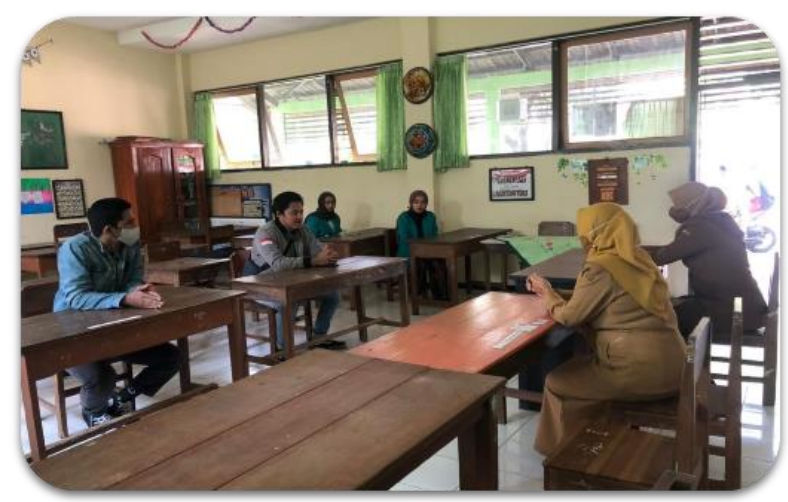

Gambar 4. Sosialisasi Pondok Daring (dok. KKN-PPM Kel.59)

\section{KESIMPULAN}

Pondok daring yang diselenggarakan oleh Mahasiswa Kuliah Kerja Nyata (KKN) Unisma diselenggarakan di Balai Dusun Banjar Tengah, Desa Sumbersekar, Kec Dau, Kab Malang. Kegiatan tersebut bertujuan untuk mencerdaskan perserta didik di masa pandemi covid-19 sekaligus menjadi media yang memudahkan komunikasi pihak sekolah terhadap murid-muridnya.

Pondok daring sendiri merupakan media yang mematuhi protokol kesehatan covid19 dan dengan persetujuan tertulis dari wali murid, kegiatan tersebut bertujuan untuk membantu pelajar yang kesulitan dalam memahami pelajaran dari sekolah. Oleh karena itu, pondok daring dapat menjawab keluhan dari orang tua selama masa pandemi terkait sistem daring yang diwajibkan di beberapa wilayah termasuk dusun banjar tengah desa sumbersekar tersebut karena mayortitas penduduk dusun banjar tengah adalah petani atau 
tukang kebun sehingga mereka mempunyai keterbatasan untuk pembelian kuota internet dan keterbatasan waktu untuk mengawasi dan membimbing anak-anaknya.

Pelaksanaan pondok daring meliputi penyediaan wifi gratis dan pengawasan sekaligus bimbingan kepada peserta didik sehingga peserta didik dapat belajar dengan nyaman dan lebih mudah memahami materi yang diberikan oleh sekolah. Kegiatan ini berlangsung selama tiga minggu dan setelah kegiatan pondok daring tersebut mahasiswa unisma membuatkan grup untuk tindak lanjutan daripada pondok daring sendiri yang bertujuan untuk mewadahi dan membantu peserta didik ketika mengalami kesulitan untuk memahami pelajaran.

\section{DAFTAR RUJUKAN}

Aprilia, M., Suparman, Eliana, E., Khairunnissa, \& Sugiarti. (2020). Pelatihan Musikalisasi Gurindam sebagai Upaya Pendidikan Karakter bagi Siswa SMA. Jurnal Inovasi Hasil Pengabdian Masyarakat (JIPEMAS), 3(2), 111-119. https://doi.org/10.33474/jipemas.v3i2.4754

Bilfaqih, Y., \& Qomarudin, M. N. (2015). Esensi Pengembangan Pembelajaran Daring (1st ed.). Yogyakarta: Deepublish.

Dalimunthe, R. A. A. (2015). Strategi Dan Implementasi Pelaksanaan Pendidikan Karakter Di Smp N 9 Yogyakarta. Jurnal Pendidikan Karakter, 5(1), 102-111. https://doi.org/10.21831/jpk.v0i1.8616

Ghirardini, B. (2011). E-learning methodologies: a guide for designing and developing elearning courses. United Nations: ome : Food and Agriculture Organization.

Haryanti, P., Hidayati, A., Rodliyah, I., Nisful Laili, C., \& Saraswati, S. (2020). Sosialisasi Literasi Keuangan Syariah Pada Anak Usia Dini. Jurnal Inovasi Hasil Pengabdian Masyarakat (JIPEMAS), 3(2), 136-145. https://doi.org/10.33474/jipemas.v3i2.6584

Kurniasih, K., Rahmati, N. A., Umamah, A., \& Widowati, D. R. (2019). English Conversation Class (ECC) Untuk Menciptakan English Environment Di SMA Islam Nusantara (SMAINUS). Jurnal Inovasi Hasil Pengabdian Masyarakat (JIPEMAS), 2(2), 161-169. https://doi.org/10.33474/jipemas.v2i2.2571

Nichols, M., \& McLachlan, C. (2006). E-learning and early childhood teacher education: what does the future hold? Не Кири (the Word), 1(1), 17-28. Retrieved from https://www.hekupu.ac.nz/article/e-learning-and-early-childhood-teachereducation-what-does-future-hold

Sobron, A. ., Bayu, Rani, \& S, M. (2019). Pengaruh Daring Learning terhadap Hasil Belajar IPA Siswa Sekolah Dasar Abstrak. In Seminar Nasional Sains \& Entrepreneurship (Vol. 1, pp. 1-5). Retrieved from http://conference.upgris.ac.id/index.php/snse/article/view/204/136 